\title{
Tutoring support as a pedagogical condition of arrangement of interpersonal communication of pupils of primary school age in the inclusive educational establishment
}

\author{
H. O. Skyba \\ Bohdan Khmelnytskyi Melitopol State Pedagogical University, Melitopol, Ukraine \\ Corresponding author. E-mail: annaskiba13@gmail.com
}

Paper received 21.01.20; Accepted for publication 06.02.20.

\begin{abstract}
https://doi.org/10.31174/SEND-PP2020-219VIII87-10
\end{abstract}
\begin{abstract}
The paper is devoted to the problems of development of skills of interpersonal communication of pupils of primary school age in the inclusive educational establishment. It reflects the main practical problems of the implementation of inclusive education in the Ukrainian schools. It substantiates the necessity of application of tutoring support as a pedagogical condition of the formation of interpersonal communication of pupils of primary school age. The author proposes own definition of the term "tutoring support" and gives the examples of the tools of tutoring support.
\end{abstract}

Keywords: education, inclusive school, tutoring support, children with special educational needs, discrimination.

Problem statement. According to the UNESCO Convention against Discrimination in Education adopted on December 14,1960 , every person has the right to study at the general education environment, in spite of sex, economic condition or availability of the disability status. According to this Convention, the children with special educational needs have a right to get education freely in the general environment without any manifestations of discrimination. According to this document the disability is not a barrier for teachers; this is discrimination which is a barrier [14]. This attitude is official for UN member states, including Ukraine. Inclusive education is a tool of exercise of the right to education of each person in general and children with special educational needs, the most of which have a disability status, in particular.

The Concept of the inclusive education development [15] explaining the purpose, tasks, principles and fundamental ways of the inclusive education implementation was approved by the order of the Ministry of Education and Science of Ukraine on the first day of October, 2010.

This is a time of the formation and improvement of the regulatory and legal framework regulating the activity of the education system employees on all levels; establishment of education and the development environment in the educational institutions according to new tasks; implementation of continuing education courses for teachers and the improvement of the talent development framework for professionals working under conditions of the inclusive education; performance of the active educational work among parents and citizens.

However, it should be noted that such an important problem in this field as ill-preparedness of society to the acceptance of children with special educational needs particularly in the educational environment and low level of preparedness of primary school age to the communication with such children remain unaddressed. This is often the reason of exclusion of such pupils from the social network of age-mates and leads to discrimination of persons with special educational needs, i.e. undermines the main goal of the inclusive education.

The analysis of researches. The research topic requires study of sources according to three courses: inclusive education, tutoring support and interpersonal communication of children of primary school age.
The theoretical and practical aspects of implementation on inclusion into the education system of Ukraine are considered in the papers of such domestic scientists and practical persons as I. Bilozerska, L. Budiak, A. Kolupaieva, N. Kompanets, Z. Leniv, R. Moiseienko, Yu. Naida, T. Sak, O. Taranchenko etc.

In spite of the fact that the profession of tutor is not specified in the national classifier of professions, the system of tutor's work and the tutoring support gain more and more popularity; they are studied and implemented by the present-day pedagogical community actively. The various aspects of tutoring are presented in the papers of I. Karpenkova, L. Moskalova. V. Osadchyi, K. Osadcha, S. Podplota, R. Polieshko, V. Chorna, T. Shvets, D. Shulzhenko, V. Shchors, I. Yakovenko.

The papers of the following scientists are devoted to the problems of interpersonal communication and interpersonal relations of the pupils of primary school age: $\mathrm{N}$. Bibik, T. Hurova. V. Kovalenko. O. Leontiev, M. Lisina. S. Nikolaienko, M. Novak, O. Protsenko, V. Salk, M. Sidun, H. Ulunova, O. Khmyzova etc.

Goal of the paper. The goal of our research is a substantiation of the topicality of tutoring support as a necessary pedagogical condition of the development of skills of interpersonal communication of primary school pupils in the inclusive environment.

Presentation of basic materials. Inclusive education is a system of educational services guaranteed by the state based on the principles of non-discrimination, consideration of human variety, efficient involvement and inclusion of all participants into the educational process [5, p. 10].

The notion of "discrimination" requires separate explanation. The first dictionary of the Ukrainian language within 1970-1980 years gives the following interpretation of the word "discrimination": "limitation or deprivation of rights of certain categories of citizens according to their ethnicity or national identity, political and religious views" [2]. The same definition is presented both in edition of 2005 year [4, p. 298]. The understanding of discrimination on the basis of disability status appeared in the society after signing of the Convention of the Rights of Persons with Disabilities by Ukraine in 2006. This understanding means "any differentiation, exclusion or limitation on the basis of disability status, having purpose or resulting in the understatement or the objection of the recognition, exercise or 
enjoyment of all human rights and fundamentals freedoms on the same basis as other people do in the political, economical, social, cultural, civil or any other field. It includes all forms of discrimination, including the rejection of reasonable accommodation" [7].

The manifestations of some genetic diseases are rather unpleasant for people around, in spite of their complete safety for life and health. For example, some forms of neuromuscular dystrophy lead to facial muscles atrophy and, as a result, making it impossible to keep mouth close, causing the fact that saliva falls on clothes, hands and the desk; indistinct pronunciation of words. The scientists emphasize that the intellect is in the normal condition under the progressive muscular dystrophy [3], so such pupils may study at the general educational establishment with the inclusive form of study.

However, the most of primary school pupils do not know how to behave in such situations and want to avoid the immediate contact on a gut level when they face the physical or psychological differences and non-standard reaction of adults to the behavior of other children (even with the differences in the schedule of lessons attendance). So, the child with special educational needs is excluded from the interpersonal communication of pupils in the group. And this is the very moment of beginning of the future and already conscious discrimination of person with special educational needs.

Consequently, the child with the special educational needs is lonely, even being in the group of pupils; he/she does not have a partner for communication. It is a common fact that the communication is a key factor facilitating the implementation of the inclusive education goals:

- cognitive, physical, social and emotional development of children with special educational needs;

- socialization of children with special educational needs and their personal fulfillment as the fully-fledged member of a society;

- development of empathy from children with typical level of development and tolerant attitude to the differences between people.

So, the development of communication skills and communicative tolerance of each pupil, starting from the first form is one of the main focus areas of professionals from primary school with the inclusive education form.

Currently the term "communication" does not have the unified agreed-upon definition. The various scientists propose their definitions, emphasizing the goals, tasks, form or structure. We think that the definition of M. Lisina is such as reflects the essence of the phenomenon in the inclusive environment the best of all: "communication is an interaction of two (or more) persons focused on the coordination and joining their efforts for the purpose of building of relations and achievement of common result" [8].

The problem and attitude to the assessment is another important question arising in the inclusive environment.

Requirements to the assessment of academic achievements of both pupils with special educational needs and pupils with typical development are determined in the Criteria of assessment of academic achievements of pupils (educatees) in the system of general education (order no. 329 dd. April 13, 2011) [11]. In such a case the pedagogical community understands that requirements to the assessment of these two categories of pupils can not be the same due to psychophysical peculiarities of pupils with special educational needs. In view of this the academic achievements of pupils with special educational needs are assessed according to the scope of materials specified by the individual curriculum. So, the levels of academic achievements (primary, sufficient, average and high) shall be retained for all pupils, and the criteria of assessment shall be within the scope of the materials according to 12-point system, specified in the individual curriculum of each pupil separately [9].

Such an attitude of the applicable law may attract controversy on the part of parents who do not know the system of inclusive education structure. The form master shall hold the introductory discussions with parents before the beginning of the academic year for the purpose of explanation of system and criteria of assessment in the inclusive form in order to avoid a controversy.

And the work with children shall be carried out on another level. In fact, child sees that the tasks are performed on various levels and the grades for their performance are equal. Child asks a question "why?". The teacher shall not only say to the child "it needs to be like that" or to explain the grade of child with special educational needs, emphasizing his/her weaknesses. The ignoring strategy is also a weak strategy. As Yu. Shevchenko specifies: "One should not make child with disabilities stand out from other children due to the fact that it is childhood which is the time when mental health, skills, abilities and temper are formed. Support of other people helps such children to get well", [13, p. 67]. So, the teacher shall use this situation as the "educating" and "learning" one. He/she shall teach every child to understand the grade correctly and to form the proper attitude to the assessment in general; to teach to compare own "today's" progress and achievements with own yesterday's results; to form the ability to assess own progress independently; to understand the reasons of assessment differences.

Currently Ukraine is at the very beginning of the implementation of inclusive education experience. However, it is clear already at this initial stage that the functions of teacher shall exceed the common limits, and the new challenges require new approaches. Naturally, the abovementioned problems of the inclusive education in primary school may be solved only through collaborative work of all professionals: teacher, teacher's assistant, psychologist, speech therapist, specialist on mental defects and physical handicaps and parents. However, it is the teacher who is a main professional working with groups of children and parents constantly.

Work with pupil's group and work with child with special educational needs requires additional special knowledge due to the fact that the needs of every such child are really unique and special. The most of children with special educational needs may study at the general educational establishment without continuous support of parents, medical officer of child's assistant according to their health indicators. So, the primary school teacher and his/her assistant shall be able to arrange the proper environment in the classroom, to adapt the teaching and learning materials, to keep an eye on the preservation of psychologically comfort climate in the form and to implement the educational methods and approaches being various for both categories of pupils. 
Being on the verge of teaching and psychological support, it is the tutoring support which is the necessary pedagogical condition which helps the teacher and his/her assistant to solve this range of complicate tasks.

N. Abramovskykh and Ye. Kazaieva propose the following definition of the tutoring support: "Tutoring support is a pedagogical activity as to the customization of the education process focused on the identification and the development of the motives of educational activity and interests of pupil, search for educational resources for drawing up the individual education program, on the work with the educational request of the family, formation of pupil's learning reflection" [1, p. 3]. However we think that this definition is incomplete for inclusive education and shall be specified. In fact, as I. Karpenkova specifies: "any school activity is usually educational for pupils with special educational needs" [6, p. 25]. In addition, child learns to interact with age-mates and adults in the general education environment.

I. Karpenkova emphasizes that the "Tutoring activity includes three vectors: social (resources of communication, interaction with age-mates and other adults); cultural and objective (includes the fact that the educational activity includes also the element of culture, its heritage, as well as the interdisciplinary interaction) and the anthropological (provides for pupil's understanding of the requirements raised especially to him/her in the implementation of his/her educational program)" [6, p. 32].

Combining the understanding of tutoring support as a condition of education customization and socialization of child with special educational needs, we provide our definition of tutoring support. We think that the tutoring support is a psychological and pedagogical activity focused on the development of skills of interpersonal communication of child with special educational needs and his/her age-mates and adults, acquirement of social rules and standards of behavior, drawing up and support of individual educational program and the development of independent learning skills.

The system of questions is a main practical technique of tutoring support implementation in the educational and pedagogic activity. It is the dialogue between the teacher and pupil which helps child to correlate his/her actions and consequences, to learn to do critical thinking, to extend and to give meaning to his/her social experience. So, the child won't just wait for ready answer and response to the words of adult; he/she will be proactively involved into the process of his/her self-development and self-improvement. Consequently, this will facilitate the development of interpersonal communication skills development. Moreover, the dialogue enables to comply with the principle of freedom and equality in communication.

The examples of tutoring support tools include the pupil's personal diary and the plan of disciplines study.
Pupil's personal diary is necessary particularly for pupil in order to record his/her thoughts or feelings for their further discussion with the assistant, teacher or psychologist. The tutoring support does not provide for reviewing the text of diary without pupil's permission.

The team of professionals draws up the individual program of development for pupils with special educational needs at the beginning of the year; the program shall specify all necessary data as to modification or adaptation of school curriculum. However, the tutoring support provides for generation of own plans for study of disciplines by the pupil in cooperation with the teacher or the assistant. Child's involvement into plan generation is compulsory. However, plan execution depends on child's age peculiarities.

The interactive game is another efficient toll of implementation of tutoring support facilitating the development of skills of interpersonal communication of primary school pupils under the conditions of the inclusive environment. As Yu. Shevchenko specifies, the conditions for the development of creative abilities of children are created due to implementation of interactive games into the education system [12, p. 361]. Material for interactive games may be rather various. The Ukrainian folk tales hold a specific place in the educational system. In fact, as the scientists specify: «Different behavioral strategies can serve as a starting point for discussing personal stories and shaping personalized values. Characters of folk tales, as valuable educational material, can effectively demonstrate both imaginary activity, indifference, and escape into illusion. Being a way of understanding different types of behavior in an unfavorable children's environment, fairytales can become a valuable resource for overcoming fears, impatience, loneliness in case if a teacher can stimulate children's imagination and select a proper fairytale, which will meet the needs of every single learner» [15, p. 253].

The conclusions and the prospects for the further experimental investigations. The efficient formation of interpersonal communication of primary school age pupils in the inclusive environment depends on the proper arrangement of the educational system, correctly built system of cooperation of all participants of the teaching and educational process and the use of pedagogical technologies facilitating the customization of the teaching and educational process, development of tolerance, self-sufficiency and strengths of personality. It was determined that the tutoring support technology complies with the specified requirements.

Further experimental investigation provides for making common sense of the specified theoretical provisions and the development of certain recommendations as to the implementation of tutoring support into the educational process.

\section{ЛІТЕРАТУРА}

1. Абрамовских Н. В. Тьюторство: история и современность/Н. В. Абрамовских, Е. А. Казаева.//Вестник Шадринского государственного педагогического института. 2013. - №3. - С. 156-162.

2. Академічний тлумачний словник української мови (19701980pp) [Е. ресурс] - Режим доступу до ресурсу: http://sum.in.ua/s/dyskryminacija.

3. Бадалян О. Л. Невропатология [Е. ресурс]/О. Л. Бадалян//Москва: Просвещение. - 1987. - Режим доступу до pecypcy:http://medbib.in.ua/progressiruyuschiemyishechnyie-distrofii.html.

4. Великий тлумачний словник сучасної української мови: 250000/уклад. та голов. ред. В. Т. Бусел. - Київ; Ірпінь: Перун, 2005. - VIII, 1728 с. 
5. Інклюзивне навчання у закладах загальної середньої освіти: керівництво для тренерів/[Н. Софій, Ю. Найда, В. Маланчій]. - Київ, 2018. - 174 с.

6. Карпенкова I. В. Тьютор в інклюзивній школі: супровід дитини з особливостями розвитку/I. В. Карпенкова., 2018. 118 с. - (Видавничий дім «Александровська»).

7. Конвенція про права осіб з інвалідністю [Е. ресурс] - Режим доступу до ресурсу: http://search.ligazakon.ua/1_doc2.nsf/link1/MU06281.html.

8. Лисина М. И. Формирование личности ребёнка [Е. peсурс]/М. И. Лисина//Питер. - 2009. - Режим доступу до реcypcy:

https://bookap.info/genpsy/lisina_formirovanie_lichnosti_reb enka_v_obshchenii/g13.shtm\#1.

9. Миронова С. Диференційований підхід в оцінюванні навчальних досягнень учнів з особливими освітніми потребами/Світлана Миронова.//Журнал «Заступник директора школи». - 2018. - №1.

10. Наказ Міністерства освіти і науки України про затвердження Концепції розвитку інклюзивного навчання [Е. peсурс] - Режим доступу до ресурсу: https://mon.gov.ua/ua/npa/pro-zatverdzhennya-kontseptsiirozvitku-inklyuzivnogo-navchannya.

11. Наказ Міністерства освіті і науки України про затвердження Критеріїв оцінювання навчальних досягнень учнів (вихованців) у системі загальної середньої освіти [Е. ресурс ] - Режим доступу до ресурсу: https://zakon.rada.gov.ua/laws/show/z0566-11.

12. Шевченко Ю. М. Використання інтерактивної гри в умовах навчання дітей з особливими потребами в початковій школі/Ю. М. Шевченко.//Вінницький державний педагогічний університет імені Михайла Коцюбинського. - 2016. - С. 360-363.

13. Шевченко Ю. М., Кубрак А. Особливості різних підходів в організації інклюзивного навчання//Психологія та педагогіка: методика та проблеми практичного застосування: 3б. тез наукових робіт учасників міжнародної науковопрактичної конференції: Львів: ГО «Львівська педагогічна спільнота», 2015. - С. 67-70.

14. Convention against Discrimination in Education [E. peсурс]//UNESCO. - 1960. - Режим доступу до ресурсу: https://unesdoc.unesco.org/ark:/48223/pf0000114583.page=1 18.

15. Development of a System for Improving Future Teachers' Readiness for the Child's Spiritual and Moral Development in a Cross-Cultural Space/Y.Shevchenko, L. Moskalyova, O. Kanarova, O. Poznanska.//Journal of History Culture and Art Research. - 2019. - №8 (4). - C. 251-261.

\section{REFERENCES}

1. Abramovskykh N. V. Tutoring: the past and the present/N. V. Abramovskykh, Ye. A. Kazaieva//Bulletin of Shadrinsk State Pedagogical Institue. - 2013. - No. 3. - P.156-162.

2. General purpose dictionary of Ukrainian language (1970-1980 years) [E. media] - Resource is available at: http://sum.in.ua/s/dyskryminacija.

3. Badalian O. L. Neuropathology [E. media]/O. L. Badalian//Moscow: Prosveshcheniye. - 1987. - Resource is available at: http://medbib.in.ua/progressiruyuschie-myishechnyiedistrofii.html.

4. The big dictionary of present-day Ukrainian language: 250000/maker and editor-in-chief V. T. Busel. - Kyiv; Irpin: Perun, 2005. - VIII, 1728 p.

5. Inclusive education in the general secondary education establishments: textbook for $\operatorname{coach} /[\mathrm{N}$. Sofii, Yu. Naida, V. Malanchii]. - Kyiv, 2018. - 174 p.

6. Karpenkova I. V. Tutor in the inclusive school: support of child with special needs/I. V. Karpenkova., 2018. - 118 p. - (Publishing house «Aleksandrovska»).

7. Convention of the Rights of Persons with Disabilities [E. media] - Resource is available at: http://search.ligazakon.ua/l_doc2.nsf/link1/MU06281.html.

8. Lisina M.I. Formation of the child's personality [E. media]//Piter. - 2009. - Resource is available at https://bookap.info/genpsy/lisina_formirovanie_lichnosti_reb enka_v_obshchenii/g13.shtm\#1

9. Myronova S. Differentiated approach in the assessment of academic achievements of pupils with special educational needs/Svitlana Myronova//Magazine «Deputy school principal». - 2018. - No. 1 .

10. The Order of the Ministry of Education and Science of Ukraine on the approval of the Concept of the inclusive education development [E. media] - Resource is available at: https://mon.gov.ua/ua/npa/pro-zatverdzhennya-kontseptsiirozvitku-inklyuzivnogo-navchannya

11. The Order of the Ministry of Education and Science of Ukraine on the approval of the Criteria of assessment of academic achievements of pupils (educatees) in the system of general secondary education - [E. media] - Resource is available at: https://zakon.rada.gov.ua/laws/show/z0566-11.

12. Shevchenko Yu. M. The use of the interactive game under the conditions of education of children with special needs in the primary school/Yu. M. Shevchenko.//Vinnitsia Mykhailo Kotsiubynskyi State Pedagogical University. - 2016. - P. 360363.

13. Shevchenko Yu.M., Kubrak A. Special aspects of various approaches in the arrangement of the inclusive education//Psychology and education science: methodology and problems of practical application: collection of abstracts of academic papers of the participants of the international research-to-practice conference: Lviv: Non-governmental organization «Lviv pedagogical community», 2015. P. 67-70. 